\title{
PROPYLENE GLYCOL ENERGY SUPPLEMENTATION DURING PERIPARTAL PERIOD IN DAIRY COWS AND REPRODUCION EFFICIENCY PARAMETERS
}

\author{
VAKANJAC SLOBODANKA*, DRAŽIĆ M**, PAVLOVIĆ V*, GVOZDIĆ D*, JOVIČIN M***,

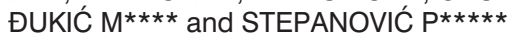

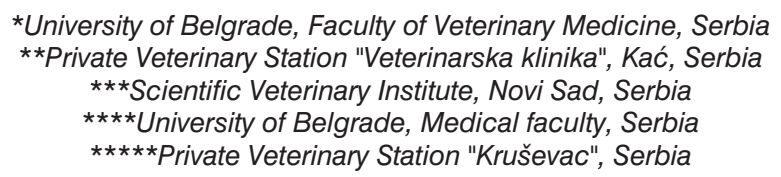

The aim of this work was to investigate the impact of two energy supplements based on propylene glycol in dairy cows diet on ovarian and follicular morphology, conception, insemination index and length of service period. A total number of 60 Holstein Friesian dairy cows, parity between 2-8, with an average milk production of $7000 \mathrm{~kg} / 305$ days of lactation were divided into three experimental groups (20 dairy cows per group). The first group of dairy cows was supplemented daily with "Energy-plus" (O1 group; $200 \mathrm{~mL}$ propylene-glycol supplement) and the second group was supplemented with "Ketal" (O2 group; 160 $\mathrm{mL}$ propylene-glycol supplement), two weeks before partus until 30 days post partum. The third experimental group were non supplemented dairy cows (O3, control group). Ultrasound examination of the reproductive system using real time echo camera Falco VET 100 (ESAOTE PieMedical, Holland, B-shaped scan with linear-array endorectal 5-8 $\mathrm{MHz}$ probe) was conducted on every animal starting from day 40 postpartum. The diameters of the ovaries (left and right) and of the dominant follicle(s) were recorded. Ultrasound testing was repeated on day 50 and 60 postpartum only in cows which in the meantime were not inseminated. Reproduction efficiency parameters (conception rate, number of inseminations and length of service period) were recorded individually. The statistical significance of the differences between groups was tested using ANOVA with LSD test at the level of significance $p<0.05$, chi-square test and Kaplan-Meier survival analysis (the length of service period).

There was no significant impact of the propylene glycol supplementation on the ovarian and follicular morphology at the first ultrasound examination. At the second ultrasound examination there was a significant difference between left ovarian dominant follicle diameter in the control and supplemented dairy cows (1.67 \pm 0.53 vs $1.12 \pm 0.29$ and $1.11 \pm 0.35 \mathrm{~cm}, p<0.05, \mathrm{O} 3 \mathrm{vs} \mathrm{O} 1$ and $\mathrm{O} 2$, respectively). The cumulative percentage of conception after the first 
and second insemination was $60 \%, 81 \%$ and $25 \%$ in groups 01,02 and 03 , respectively $(p<0.05$, chi-square test). The insemination index was lowest in group $\mathrm{O} 2$ and statistically significant differences were found between groups $\mathrm{O} 2$ and $\mathrm{O} 3(1.69 \pm 0.79: 3.38 \pm 1.36$, respectively, $p<0,05)$. The length of the service period was significantly $(p<0.05$, LSD test) shorter in the 02 group (100 \pm 35 days) compared to groups O1 and $\mathrm{O} 3$ (168 \pm 59 and $157 \pm 52$ days, respectively), that was confirmed by the Kaplan-Meier survival analysis of days open periods.

The use of propylene glycol supplement in dairy cows diet during peripartal period induced higher percentage of pregnancy rates after the first and second insemination, significantly shortened the length of the service period and reduced the insemination index.

Key words: dairy cows, propilen glycol, peripartal period, reproduction efficiency

\section{INTRODUCTION}

The early lactation period is characterized by a negative energy balance (NEB), which is primarily caused by an inadequate relationship between the requirements for milk production and feeding opportunities (appetite-ingestion) (Bell, 1995). Fertility of dairy cows reflects the cumulative effect of metabolic, endocrine, and health components that are modified by the intensive selection for high milk yield (Jorritsma et al., 2003).

Shortly after calving, between days 7-14 post partum, the follicle-stimulating hormone (FSH) level in dairy cows begins to increase. Successful development of follicles depends, besides the effects of $\mathrm{FSH}$, also on the luteinizing hormone (LH) pulse frequency (Roche et al, 1998). For cows that have passed the lowest level of NEB, the return of physiological LH pulse frequency is recognized as a sign of the establishment of normal postpartum ovarian activity (Canfield et al., 1990). It is assumed that NEB does not interfere with follicular waves during the early postpartum period and follicular dynamics is a response to increased blood concentrations of $\mathrm{FSH}$, which is synchronized to the end of pregnancy. In the first weeks of lactation, there is insufficient $\mathrm{LH}$, but not FSH secretion, and therefore NEB does not affect the regular start of follicular growth, which depends only on FSH (Beam et al., 1997; Pate, 1999; Savio et al., 1990).

During the postpartum period the reproductive system of dairy cows undergoes major changes. After calving the uterus involutes, and the hypothalamus-pituitary-gonadal axis restarts estrus cyclicity, that practically "resets" the reproductive system (Pate, 1999). The development of dominant follicles in dairy cows occurs in waves and the majority of the estrus cycles consist of two to three such waves. Follicular waves usually occur on the $2^{\text {nd }}$ and $9^{\text {th }}$ day of the estrus cycle, or on the $2^{\text {nd }}, 9^{\text {th }}$ and $16^{\text {th }}$ day, depending on the number of waves (Sirois et al., 1988). At the time around calving the ovarian follicles in cows are not larger than $5 \mathrm{~mm}$ in diameter. During the first 25 days after calving, concurrent to the reduction in energy deficit the number of Class 3 follicles (10- 
$15 \mathrm{~mm}$ in diameter) increases. Class 1 and 2 follicles (3-5 and 6-9 $\mathrm{mm}$ in diameter, respectively) shift from lower to upper class (Lucy et al., 2007). The final diameter of the dominant follicle and the production of 17ß-estradiol are influenced by metabolic factors. As the energy balance improved after the lowest level of NEB there is improvement in growth of dominant follicles and higher levels of 17ßestradiol were detected (Beam et al., 1997; 1998).

It is generally accepted that in order to achieve optimal economic performance one dairy cow should have a calf every year. This goal can be achieved with successful conception before day 85. postpartum. It is also important that the early return of normal ovarian cycle (follicular and luteal phase of estrus cycle) is associated with visible signs of estrus (Opsomer et al., 1998). The early occurrence of estrus is important because in cows up to the $60^{\text {th }}$ day postpartum there is a negative correlation between the number of cycles and the length of the service period (Canfield \& Butler, 1990). The timing of the first estrus after calving is very variable and it ussually occurs between days 30-80 postpartum. The fact is that first visible signs of estrus are not a reliable signs of early ovarian activity. Allrich (1994) showed that the first postpartum ovulation in dairy cows is usually "quiet", with no visible signs of estrus. It is the influence of progesterone on the brain structures that leads to visible external symptoms of estrus. Progesterone is secreated by the corpus luteum, formed after the first postpartal ovulation, and this steroid hormone makes the brain susceptible to estradiol effects during the next follicular phase of the estrus cycle.

Propylene glycol (propadiol-1,2 or propane-1,2-diol; PG) is a sweet, hygroscopic, viscous liquid with glucoplastic properties in dairy cows. It is routinely used per os in the treatment of ketosis, with an assumption that it can quickly increase the blood glucose level (Butler et al., 2006; Rizos et al., 2008). After absorption from the digestive system most of the PG enters the liver via the portal vein. In the hepatocytes, PG is metabolized by the lactate aldehyde pathway, into lacto-aldehyde which is then oxidized to lactate. Furher oxidation of lactate to pyruvate is followed by the formation of oxaloacetate (OA), which is the starting compound in the process of gluconeogenesis (Veltman et al., 1998, Grummer et al., 1994). The oral use of PG during the postpartal period is one way to overcome the NEB and reduce the likelihood of ketosis and not weaken the reproductive function (Studer et al., 1993, Grummer, 1995). In cows treated with $P G$ the first ovulation occurred earlier than expected and the length of the first luteal phase was within physiological limits. In the control group of dairy cows active luteal phase after the first postpartal ovulation lasts only 7.3 days, indicating a short and infertile estrous cycle (Miyoshi et al., 2001).

The service period represents the time from calving to successful conception. The average length of service period for dairy cows is between $80-90$ days (Chebel, 2008). Early postpartum insemination increases the number of calves and reproductive efficiency, but it requires a higher number of semen doses used per successful pregnancy. Chabel (2008) also indicated that the first postpartum insemination may be practiced as early as 40 days after calving with an acceptable reproductive performance. The aim of this work was to investigate the impact of two energy supplements based on propylene glycol in dairy cows 
diet on the ovarian and follicular morphology, conception, insemination index and length of service period.

\section{MATERIAL AND METHODS}

The total number of 60 Holstein Friesian dairy cows, parity between 2-8, with an average milk production of $7000 \mathrm{~kg} / 305$ days of lactation were divided into three experimental groups. The first group of dairy cows was supplemented daily with "Energy-plus" (O1 group, $200 \mathrm{~mL}$ propylene-glycol supplement) and the second group was supplemented with "Ketal" (O2 group, $160 \mathrm{~mL}$ propyleneglycol supplement), two weeks before partus until 30 days postpartum. The third experimental group represented the non supplemented dairy cows $(\mathrm{O} 3$, control group).

Ultrasound examination of the reproductive system using real time echo camera Falco VET 100 (ESAOTE PieMedical, Holland, B-shaped scan with lineararray endorectal $5-8 \mathrm{MHz}$ probe) was conducted at least twice on every animal starting from day 40 postpartum. The diameters of ovaries (left and right) and dominant follicle(s) were recorded. Ultrasound testing was repeated on day 50 or 60 postpartum only in those cows which in the meantime were not inseminated. Pregnancy was verified by ultrasound examination 45 to 60 days following insemination. Reproduction efficiency parameters (conception rate, number of inseminations and length of service period) were recorded individually. The statistical significance of the differences between groups were tested using ANOVA with LSD test at the level of significance $p<0.05$, chi-square test $(p<0.05)$ and Kaplan-Meier survival analysis (the length of service period).

\section{RESULTS}

The results of ovarian (left and right) and dominant follicle diameters recordings at the first and second ultrasound examinations are shown in Table 1.

Table 1. Ovarian (left and right) and dominant follicle diameter recordings $(\overline{\mathrm{x}} \pm \mathrm{SD}, \mathrm{cm})$ at the first and second ultrasound examination

\begin{tabular}{|c|c|c|c|c|c|}
\hline \multirow{2}{*}{ Echo. } & Group & $\begin{array}{c}\text { Right } \\
\text { ovary }\end{array}$ & $\begin{array}{c}\text { Left } \\
\text { ovary }\end{array}$ & $\begin{array}{c}\text { Right } \\
\text { ovary follicle }\end{array}$ & $\begin{array}{c}\text { Left } \\
\text { ovary follicle }\end{array}$ \\
\hline \hline \multirow{3}{*}{ I } & O1 & $2.73 \pm 0.71$ & $2.76 \pm 0.66$ & $1.16 \pm 0.38$ & $1.18 \pm 0.36$ \\
\cline { 2 - 6 } & O2 & $2.48 \pm 0.38$ & $2.62 \pm 0.55$ & $1.15 \pm 0.53$ & $1.04 \pm 0.26$ \\
\cline { 2 - 6 } & O3 & $2.90 \pm 0.73$ & $2.66 \pm 0.66$ & $1.22 \pm 0.35$ & $1.17 \pm 0.37$ \\
\cline { 2 - 6 } & mean & $2.68 \pm 0.63$ & $2.68 \pm 0.61$ & $1.17 \pm 0.42$ & $1.14 \pm 0.33$ \\
\hline \hline \multirow{3}{*}{ II } & O1 & $2.71 \pm 0.54$ & $2.71 \pm 0.42$ & $1.29 \pm 0.27$ & $1.12 \pm 0.29 \mathrm{a}$ \\
\cline { 2 - 6 } & O2 & $2.86 \pm 0.80$ & $2.95 \pm 0.58$ & $1.28 \pm 0.33$ & $1.11 \pm 0.35 \mathrm{~b}$ \\
\cline { 2 - 6 } & O3 & $3.04 \pm 0.71$ & $2.96 \pm 0.60$ & $0.97 \pm 0.24$ & $1.67 \pm 0.53 \mathrm{a}, \mathrm{b}$ \\
\cline { 2 - 6 } & mean & $2.87 \pm 0.69$ & $2.87 \pm 0.54$ & $1.18 \pm 0.31$ & $1.23 \pm 0.42$ \\
\hline
\end{tabular}


The results in Table 1 indicate that mean values for the right ovary and follicle diameters measured 40 days post partum were $2.68 \pm 0.63$ and $1.17 \pm 0.42 \mathrm{~cm}$, respectively. At the day 50 postpartum the mean values for the right ovary and follicle diameters were $2.87 \pm 0.69$ and $1.18 \pm 0.31 \mathrm{~cm}$, respectively. There were no statistically significant differences between the mean right and left ovary and right ovary dominant follicles diameter between experimental groups. The left ovary diameter mean values were not significantly different between groups at the second ultrasound examination. However, the left ovary dominant follicle diameter mean value in the control group of dairy cows $(1.67 \pm 0.53 \mathrm{~cm}, 03)$ at second ultrasound examination was significantly higher $(p<0.05)$ compared to the other experimental groups $(1.12 \pm 0.29$ and $1.11 \pm 0.35 \mathrm{~cm}, \mathrm{O} 1$ and $\mathrm{O} 3$, respectively).

The conception rates results of experimental groups of dairy cows are shown in Table 2.

Table 2. Conception rates results (total and relative number of inseminated and pregnant cows per experimental group)

\begin{tabular}{|c|c|c|c|c|c|}
\hline \multirow{2}{*}{ Group } & $\begin{array}{c}\text { Number of cows } \\
\text { per group }\end{array}$ & \multicolumn{2}{|c|}{$\begin{array}{c}\text { Number of } \\
\text { inseminated cows }\end{array}$} & \multicolumn{2}{c|}{$\begin{array}{c}\text { Number of } \\
\text { pregnant cows }\end{array}$} \\
\cline { 2 - 6 } & $\mathrm{N}$ & Number & $\%$ & Number & $\%$ \\
\hline \hline O1 & 20 & 17 & 85 & 15 & 88 \\
\hline O2 & 20 & 20 & 100 & 16 & 80 \\
\hline O3 & 20 & 19 & 95 & 16 & 84 \\
\hline \hline Total & 60 & 56 & 93 & 47 & 84 \\
\hline
\end{tabular}

The total number of cows that were inseminated was 56, representing $93 \%$ of all experimental animals, and $84 \%$ of those cows were pregnant after $1-5$ inseminations. The results of pregnancy rate after first, second and further inseminations and statistical significance of the differences between groups are presented in Figure 1.

The results of pregnancy rate presented in the Figure 1 indicate that the majority of cows treated with energy supplements based on PG conceived after the first and second postpartal insemination. Cumulative pregnancy rate after the first and second insemination in the first and second experimental group was $60 \%$ and $81 \%$, respectively. In the nonsupplemented control group 12 out of 16 cows (75\%) conceived after three or more inseminations. There is a statistically significant difference in the proportions of pregnant animals after the first, second and $\geq 3$ inseminations between two supplemented groups of dairy cows and the control group of animals (40\%:20\%:40\% and 50\%:31\%:19\% vs $12 \%: 12 \%: 75 \%$; 01 and $\mathrm{O} 2$ vs. $\mathrm{O} 3$, respectively, $\mathrm{p}<0.05$, chi-square test).

The results of the average number of semen doses (insemination index) per pregnant dairy cow are presented in Table 3. 


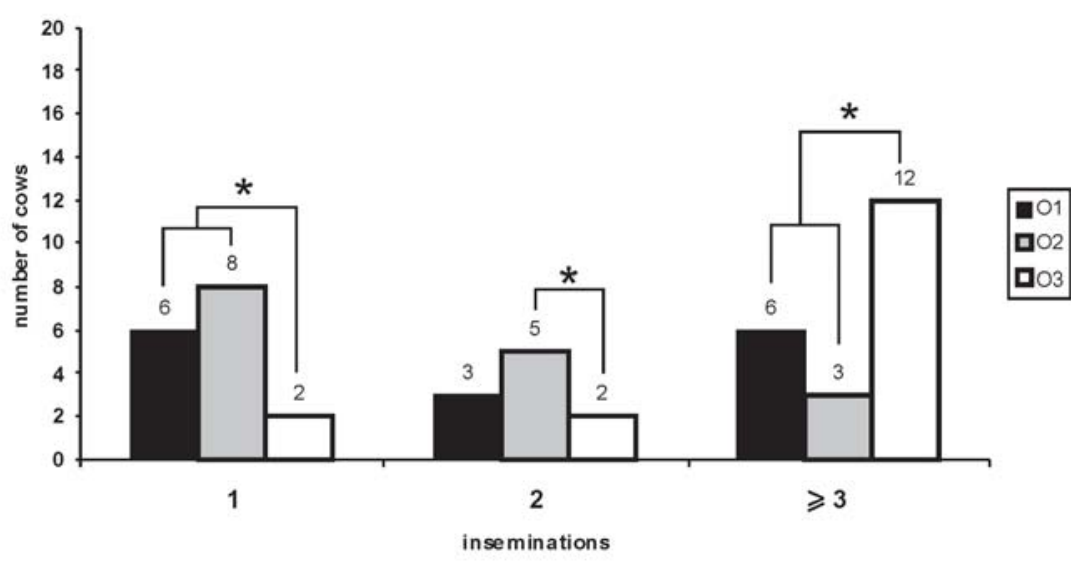

Figure 1. Pregnancy rate per experimental group according to insemination; 1 - cows recorded pregnant after the first artificial insemination, 2 - cows recorded pregnant after the second artificial insemination, $\geq 3$ - cows recorded pregnant after third or more inseminations; *- statistically significant difference between proportions $(p<0.05$, chi-square test)

Table 3. The average number of semen doses per pregnant dairy cow (insemination index)

\begin{tabular}{|c|c|c|c|c|c|c|}
\hline Group & $\mathrm{n}$ & $\overline{\mathrm{x}}$ & $\mathrm{SD}$ & Min & Max & CV\% \\
\hline \hline $\mathrm{O} 1$ & 15 & 2.60 & 1.80 & 1 & 6 & 69.41 \\
\hline $\mathrm{O} 2$ & 16 & $1.69^{\mathrm{a}}$ & 0.79 & 1 & 3 & 47.00 \\
\hline O3 & 16 & $3.38^{\mathrm{a}}$ & 1.36 & 1 & 5 & 40.30 \\
\hline \hline Total & 47 & 2.55 & 1.52 & 1 & 6 & 59.35 \\
\hline
\end{tabular}

Legend: $\mathrm{n}$ - number of pregnant cows; ${ }^{\mathrm{a}}$ Groups labeled with the same superscript are statistically different $(p<0.05$, LSD test).

The insemination index represents the ratio between the total number of inseminations and the number of pregnant cows. The insemination index was $2.60 \pm 1.80,1.69 \pm 0.79$ and $3.38 \pm 1.36$ (for $\mathrm{O} 1, \mathrm{O} 2$ and $\mathrm{O} 3$ group, respectively). There was a statistically significant difference in the insemination index between groups $\mathrm{O} 2$ and $\mathrm{O} 3$ of dairy cows $(p<0.05$; LSD test).

The results of the average number of days from calving to conception (service period, days open) are shown in Table 4.

The duration of the service period was $168.47 \pm 59.20,100.47 \pm 35.09$ and $157.25 \pm 51.50$ days (O1, $\mathrm{O} 2$ and $\mathrm{O} 3$ group, respectively). According to the obtained results there was a statistically significant difference between the first and second, and between the second and third experimental group $(p<0.05$, LSD 
Vakanjac Slobodanka et al.: Propylene glycol energy supplementation

during peripartal period in dairy cows and reproducion efficiency parameters

test). The results of Kaplan Meier survival analysis have also indicated a statistically significant difference between the second experimental group (O2, supplemented with Ketal) compared to two other experimental groups (see Figure 2).

Table 4. Number of days from calving to conception (service period, days open)

\begin{tabular}{|c|c|c|c|c|c|c|}
\hline Group & $\mathrm{n}$ & $\overline{\mathrm{x}}$ & $\mathrm{SD}$ & Min & Max & CV\% \\
\hline \hline O1 & 15 & $168.47^{\mathrm{a}}$ & 59.20 & 66 & 250 & 35.14 \\
\hline O2 & 15 & $100.47^{\mathrm{a} . \mathrm{b}}$ & 35.09 & 62 & 177 & 34.93 \\
\hline O3 & 16 & $157.25^{\mathrm{b}}$ & 51.50 & 37 & 234 & 32.77 \\
\hline \hline Total & 46 & 142.35 & 56.99 & 37 & 250 & 40.03 \\
\hline
\end{tabular}

Legend: $a, b$ - Groups labeled with the same superscript are statistically different ( $p<0.05$, LSD test).

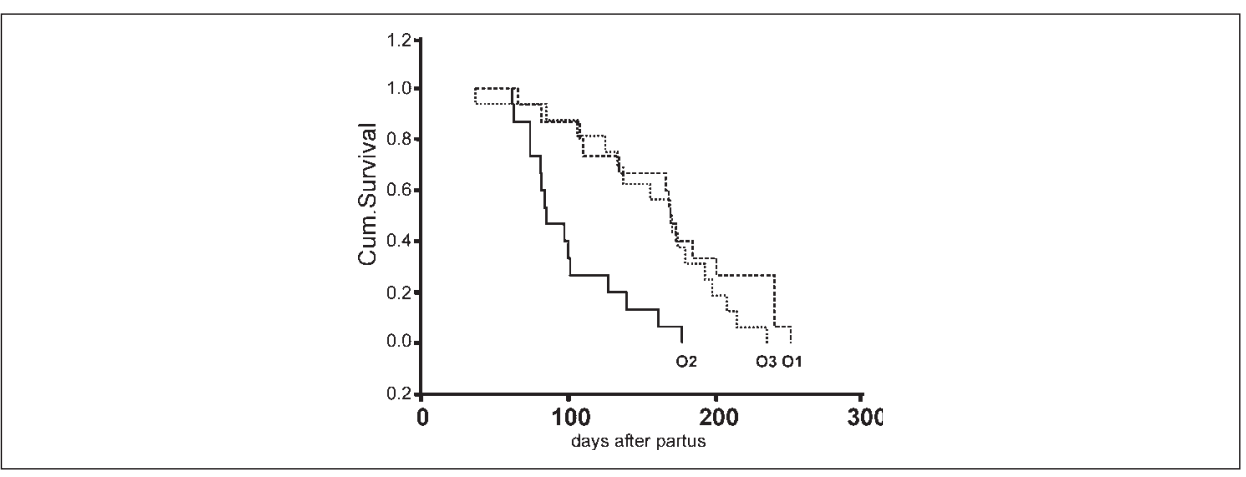

Figure 2. The results of Kaplan Meier survival analysis of days open period in all three groups of dairy cows

The results of Kaplan Meier survival analysis of days open period in all three experimental groups (Figure 2) indicate that dairy cows that were supplemented with "Ketal" (O2 group) had significantly shorter days open period compared to the other two experimental groups (O1 and $\mathrm{O} 3)$, since the cumulative survival curves for $\mathrm{O} 2$ group does not cross the survival curves for two other experimental groups.

\section{DISCUSSION}

Energy balance in lactating dairy cows can be defined as the difference between utilisable energy from dietary intake and the energy expended for body maitenance and milk production (Beam et al., 1999). Parturition represents an abrupt change from pregnancy to lactation. During pregnancy the energy input is spent on foetal growth and development, as well as body reserves accretion. 
However, at the onset of lactation tremendous metabolic demands of high milk production are supported by rapid mobilisation of lipid and protein body stores (Bauman \& Currie, 1980; Butler, 2000). Since dry matter intake (DMI) in high producing dairy cows at the early lactation is insufficient for dramatic increase of milk production, dairy cows typically experience NEB. The NEB is characterised by a loss of body reserves and may persist for 10-12 weeks of lactation (Bauman and Currie, 1980), being most intensive in the first week of lactation (Tamminga et al., 1997). During the first 3-4 weeks postpartum NEB is highly positively correlated with the interval to first ovulation (Butler, 2000). However, follicular growth and recruitment of a domminant follicle (DF) seems to be independent of energy balance (Beam et al., 1997). Furthermore, PG supplementation during early lactation had no effects on follicular dynamics, mean days to emergence of the first cohort of follicles postpartum, or days to dominance and duration of dominance for any follicular wave recorded postpartum (Rizos et al., 2008). Our results regarding ovarian and follicular morphology indicate no statistically significant difference between ovarian and DF diameter between PG supplemented and control group of dairy cows at the first ultrasound examination (Table 1). Suprisingly, we have recorded significantly higher left ovarian DF follicle diameter in the control group of dairy cows at the second ultrasound examination compared to the supplemented cows. Since the control group dairy cows conception occurred mostly after the third or more Al (75\% of pregnancies after $\geq 3$ $\mathrm{Al})$, when energy balance was corrected. This could explain the difference in left ovary follicular diameter. However, because of the relatively small number of experimental animals this problem needs further research. There was no significant difference in the right and left ovarian diameters between supplemented and control dairy cows.

Permanent decline of modern high-milking dairy cows reproductive efficiency has been documented by many researchers during the last decades (Roche, 2000; Lucy, 2001; Dobson et al., 2007). A significant worldwide decline in conception to first service in Holstein dairy cows has been recorded over the past 30 years (Beam et al., 1999, Royal et al., 2000). Decrease of reproductive efficiency is also evident as prolonged postpartal anoestrus (Thacher et al., 2006), increase number of cows in silent estrus with irregular estrous cycle duration, resulting from short luteal phase in the first few postpartal cycles (Miyoshi et al., 2001), decline in the first insemination conception rate (CR) (Lucy, 2001), as well as an increase number of cows with abnormal early embryonic development and various forms of uterine diseases, increasing embryonic and fetal mortality rate (Bouchard et al., 2003; Lucy, 2007). The final result is a decline in the reproductive efficiency with an increase of number of inseminations needed for successful conception (insemination index) (Sheldon and Dobson, 2003). It was reported that successful CR after the first insemination decreased between 1990-2000 in most European countries from 55\% to $45 \%$ (Bousquet et al., 2000). This situation had a direct influence on the increase of the number of inseminations and Lucy (2001) reported that 20 years earlier approximately 1.75 inseminations were needed for successful conception while in the last few years it has increased to more than 3 . This is important parameter of reproduction efficiency since it is 
inversely proportional to the reproduction efficiency and directly proportional to DO period (Esslemont et al., 2000). Our results indicate that CR at the first and second $\mathrm{Al}$ in supplemented dairy cows was significantly increased compared to the control group of animals (Table 3). Furthermore, cumulative pregnancy rate for first and second Al was $60 \%$ and $81 \%$ for supplemented inseminated animals. These results confirm the thesis of Chabel (2008) that first postpartum insemination may be practiced as early as 40 days after calving with an acceptable reproductive performance.

The pregnancy rate is a very significant parameter of reproductive efficiency. The energy supplement based on PG given in the peripartal (transition) period increased the number of cows which conceived after the first and second insemination (Figure 1). Miyoshi et al. (2001) reported successful conception in $57.1 \%$ of PG supplemented cows, and $33 \%$ in the control group. In our study only the first and second insemination may be linked to the influence of PG as it was applied up to the 30th day after calving. Boland et al. (1999) reported the indicators of optimal reproduction are those where $60 \%$ of cows conceived after the first insemination. The insemination index was lowest for the group of cows treated with Ketal (O2), indicating that the use of different type of PG supplement could result in the decreased number of inseminations per pregnancy.

The service period was reduced in $\mathrm{O} 2$ group of supplemented dairy cows (Table 4). It was significantly shorter indicating that Ketal supplementation could reduce the duration of the service period (Figure 2). This is in disagreement with the results of Miyoshi et al. (2001), who has reported that dietary supplementation of diary cows with PG did not affect the duration of the service period. Most authors agree that the use of energy supplements based on PG does not improve reproductive characteristics of dairy cows (Formigoni et al., 1996; Miyoshi et al., 2001; Hoedemaker et al., 2004; Chagas et al., 2007). Our results showed that some reproductive efficiency parameters could be improved by certain energy supplements. However, the sole application of PG supplement is probably not sufficient to eliminate all negative impacts of the energy deficit on reproductive efficiency. Only adequate nutrition and housing, with all the other necessary animals health and welfare control programs as a part of modern farm management, can provide a high milk production without a negative impact on reproduction efficiency in dairy cows.

\section{ACKNOWLEDGEMENTS}

This work was supported by Ministry of science and technology, Republic of Serbia, Project Grant No. 31050 and Project Grant No. 46002.

Address for correspondence:

Prof. dr Dragan Gvozdić

Department of pathophysiology

Faculty of veterinary medicine

University of Belgrade

Bul. Oslobodjenja 18

11000 Belgrade, Serbia

E-mail: gvozdic@vet.bg.ac.rs 


\section{REFERENCES}

1. Allrich RD, 1994, Endocrine and neural control of estrus in dairy cow, J Dairy Sci, 77, 2738-44.

2. Bauman DE, Currie WB, 1980 , Partitioning of nutrients during pregnancy and lactation: a review of mechanisms involving homeostasis and homeorhesis, J Dairy Sci, 63, 1514-29.

3. Beam SW, Butler WR, 1997, Energy balance and ovarian follicle development prior to the first ovulation postpartum in dairy cows receiving three levels of dietary fat, Biol Reprod, 56, 133-42.

4. Beam SW, Butler WR, 1998, Energy balance, metabolic hormones, and early postpartum follicular development in dairy cows fed prilled lipid, J Dairy Sci, 81, 121-31.

5. Beam SW, Butler WR, 1999, Effects of energy balance on follicular development and first ovulation in post partum dairy cows, $J$ Reprod Fert, 54, 411-24.

6. Bell AW, 1995, Regulation of organic nutrient metabolism during transition from late pregnancy to early lactation, J Anim Sci, 73, 2804-19.

7. Boland MP, O'Callaghan D, 1999, Nutrition and early embryonic development, Reprod Dom Anim, 34, 127-32.

8. Bouchard E, Du Trembly D, 2003, Portrait Quebecois de la reproduction. Recueil des conferences du Symposium des Bovines laitiers, Saint-Hyacinthe, 13-23.

9. Bousquet $D$, Bouchard $E$, Du Tremblay $D, 2004$, Decreasing fertility in dairy cows: myth or reality? Proc. 23. WBC Congr, Quebec, Canada, 1-7.

10. Butler ST, Pelton SH, Butler WR, 2006, Energy balance, metabolic status, and the first postpartum ovarian follicle wave in cows administered propylene glycol, J Dairy Sci, 89, 2938-51.

11. Butler WR, 2000, Nutritional interactions with reproductive performance in dairy cattle, Anim Reprod Sci, 60, 449-57.

12. Canfield RW, Butler WR, 1990, Energy balance and pulsatile LH secretion in early postpartum dairy cattle, Dom Anim Endocrinol, 7, 323-30.

13. Chagas LM, Gore PJ, Meier S, Macdonald KA, Verkerk GA, 2007, Effect of monopropylene glycol on luteinizing hormone, metabolites and postpartum anovulatory intervals in primiparous dairy cows, J Dairy Sci, 90, 1168-75.

14. Chebel CR, 2008, Voluntary waiting period: How soon is too soon, and how late is too late, West Dairy News, 8, 89-90.

15. Dobson H, Smith R, Royal M, Knight Ch, Sheldon I, 2007, The high-producing dairy cow and its reproductive performance, Reprod Dom Anim, 42, 2,17-23.

16. Esslemont SW, Kossaibati MA, 2000, The use of databases to manage fertility, Anim Reprod Sci, 60, 61, 725-41.

17. Formigoni A, Cornil MC, Prandi A, Rossi A, 1996, Effect of propylene glycol supplementation around parturition on milk yield, reproduction performance and some hormonal and metabolic characteristics in dairy cows, J Dairy Res, 63, 1, 11-24.

18. Grummer $R, 1995$, Impact of changes in organic nutrient metabolism on feeding the transition dairy cow, J Anim Sci, 73, 2820-33.

19. Grummer RG, Winkler JC, Bertics SJ, Studer VA, 1994, Effect of propylene glycol dosage during feed restriction on metabolites in blood of prepartum Holstein heifers, J Dairy Sci, 77, 3618-23.

20. Hoedemaker M, Prange D, Zerbe H, Frank J, Daxenberger A, Meyer HH, 2004, Peripartal propylene glycol supplementation and metabolism, animal health, fertility and production in dairy cows, $J$ Dairy Sci, 87, 2136-45.

21. Jorritsma R, Wensing T, Kruip TA, Vos PL, Noordhuizen JP, 2003, Metabolic changes in early lactation and impaired reproductive performance in dairy cows, Vet Res, 34, 1, 11-26.

22. Lucy CM, 2001, Reproductive loss in high-producing dairy cattle: where will it end, J Dairy Sci, 84, 1277-93.

23. Lucy CM, 2007, Ferility in high-producing dairy cows: reasons for decline and corrective strategies for sustainable improvement, Soc Reprod Fert, 64:237-254.

24. Lucy MC, 2007, The bovine dominant ovarian follicle, J Anim Sci, 85, E89-E99. 
25. Miyoshi S, Pate JL, Palmquist DL, 2001, Effects of propylene glycol drenching on energy balance, plasma glucose, plasma insulin, ovarian function and conception in dairy cows, Anim Reprod Sci, 68, 29-43.

26. Opsomer G, Coryn CM, De Kruif A, 1998, An analysis of ovarian dysfunction in high yielding dairy cows after calving based on progesterone profiles, Reprod Dom Anim, 33, 193-204.

27. Pate LJ, 1999, Effects of energy balance on ovarian function, In: Tri-State Dairy Nutrition Conference, Ohio, USA, 20-21 April, 33-40.

28. Patton J, Kenny DA, Mee JF, O'Mara FP, Wathes DC, Cook M et al., 2006, Effect of milking frequency and diet on milk production, energy balance, and reproduction in dairy cows, J Dairy Sci, 89, 5, 1478-87.

29. Rizos D, Kenny DA, Griffin W, Quinn KM, Duffy P, Mulligan FJ et al., 2008, The effect of feeding propylene glycol to dairy cows during the early postpartum period on follicular dynamics and on metabolic parameters related to fertility, Theriogenology, 69, 688-99.

30. Roche JF, Mackey D, Diskin MD, 2000, Reproductive management of postpartum cows, Anim Reprod Sci, 60-1, 703-12.

31. Roche JF, Mihn M, Diskin MG, Ireland JJ, 1998, A Review of Regulation of Follicle Growth in Cattle, J Anim Sci, 76, 16-29.

32. Royal MD, Darwash AO, Flint APF, Webb R, Woolliams JA, Lamming GE, 2000, Declining fertility in dairy cattle: changes in traditional and endocrine parameters of fertility, Anim Sci, 70, 487-502.

33. Savio JD, Boland MP, Hynes N, Roche JF, 1990, Resumption of follicular activity in the early postpartum period of dairy cows, J Reprod Fert, 88, 569-79.

34. Sheldon IM, Dobson H, 2003, Reproductive challenges facing the cattle industry at the beginning of the 21st century, Reprod Suppl, 61, 1-13.

35. Sirois J, Fortune JE, 1988, Ovarian follicular dynamics during the estrous cycle in heifers monitored by real-time ultrasonography, Biol Reprod, 39, 308-17.

36. Studer VA, Grummer RR, Bertics SJ, 1993, Effect of prepartum propylene glycol administration on periparturient fatty liver in dairy cows, J Dairy Sci, 76, 2931-9.

37. Tamminga S, Luteijn PA, Meijer RGM, 1997, Changes in composition and energy content of liveweight loss in dairy cows with time after parturition, Livestock Prod Sci, 52, 31-8.

38. Thacher WW, Bilby RT, Bartolome AJ, Silvestre F, Staples RC, Santos PEJ, 2006, Strategies for improving fertility in the modern dairy cow, Theriogenology, 65, 30-44.

39. Veltman S, Schoenberg T, Switzenbaum MS, 1998, Alcohol and acid formation during the anaerobic decomposition of propylene glycol under methanogenic conditions, Biodegradation, 9, 113-8.

\title{
ENERGETSKA SUPLEMENTACIJA PROPILEN GLIKOLOM TOKOM PERIPARTALNOG PERIODA I PARAMETRI EFIKASNOSTI REPRODUKCIJE KOD MLEČNIH KRAVA
}

\author{
SLOBODANKA VAKANJAC, DRAŽIĆ M, PAVLOVIĆ V, GVOZDIĆ D, JOVIČIN M, ĐUKIĆ M \\ i STEPANOVIĆ P
}

\section{SADRŽAJ}

Cilj ovog rada je bio da se ispita uticaj primene dva tipa energetskih dodataka u ishrani mlečnih krava na bazi propilen glikola na morfologiju jajnika i folikula, koncepciju, indeks osemenjavanja i dužinu servis perioda. U ogled je bilo uključeno ukupno 60 krava Holštajn Frizijske rase, u toku 2-8 laktacije, sa pro- 
sečnom proizvodnjom mleka od $7000 \mathrm{~kg} / 305$ dana laktacije, koje su bile podeljene u tri ogledne grupe (20 krava po grupi). Prva grupa mlečnih krava (01) je svakodnevno suplementirana peroralnom aplikacijom 200 mL "Energy-plus", druga grupa krava (O2) suplementirana je sa $160 \mathrm{~mL}$ "Ketal-a", počevši od dve nedelje pre partusa do 30 dana nakon partusa. Treću grupu mlečnih krava (O3, kontrola) su predstavljale netretirane životinje. Ultrazvučni pregled reproduktivnog sistema vršen je sa uređajem Falco VET 100 (ESAOTE PieMedical, Holland), linearnom endorektalnom sondom od 5-8 $\mathrm{MHz}$ kod svake životinje najmanje dva puta počevši od 40 dana posle partusa. Ultrazvučni pregled je ponovljen sa 50 i/ili 60 dana posle partusa kod krava koje nisu u međuvremenu osemenjene. U toku svakog pregleda su registrovani prečnik oba jajnika i dominantnog folikula. Kod svake ogledne životinje su određeni parametri efikasnosti reprodukcije: stepen koncepcije, indeks osemenjavanja i servis period. Statistička značajnost razlika srednjih vrednosti dobijenih parametara određivana je ANOVA metodom i LSD testom na nivou značajnosti od $p<0.05$, hi-kvadrat testom i Kaplan-Majerovom analizom (dužina servis perioda).

Rezultati prvog ultrazvučnog preleda su ukazali da nema statistički značajnih razlika u morfologiji jajnika i dominantnog folikula između suplementiranih grupa u odnosu na kontrolnu grupu krava. Rezultati drugog ultrazvučnog pregleda su ukazali da postoji statistički značajna razlika između srednjih vrednosti prečnika dominantnog folikula na levom jajniku kod kontrolne grupe krava u odnosu na suplementirane životinje $(1,67 \pm 0,53: 1,12 \pm 0,29$ i $1,11 \pm 0,35 \mathrm{~cm}, p<0.05$, O3:01 i O2).

Zbirne vrednosti procenta koncepcije nakon prvog i drugog osemenjavanja bile su statistički značajno više kod suplementiranih krava u odnosu na kontrolnu grupu životinja (60\% : 81\% : 25\%; 01:02:03, p<0,05, hi-kvadrat test). Najniža vrednost indeksa osemenjavanja je utvrđena kod ogledne grupe krava suplentirane Ketal-om (1.69 \pm 0.79$)$, koja je bila značajno viša u odnosu na kontrolnu grupu krava $(3.38 \pm 1.36, p<0,05)$. Dužina servis perioda je bila najmanja kod grupe krava suplementiranih Ketal-om ( $100 \pm 35$ days) i značajno se razlikovala u odnosu na ostale ogledne grupe (168 \pm 59 i 157 152 dana, O1 i O2), što je potvrđeno Kaplan Majerovom analizom.

Energetska suplementacija mlečnih krava propilen glikolom tokom peripartalnog perioda može dovesti do povećanja procenta gravidnih krava nakon prvog i drugog osemenjavanja, smanjenja vrednosti indeksa osemenjavanja i skraćenja dužine servis perioda. 